\title{
XRCC1 Gene Polymorphism Increases the Risk of Hepatocellular Carcinoma in Egyptian Population
}

\author{
Mary Naguib', Mohamed M Helwa ${ }^{2}$, Mohammed M Soliman², Mohamed \\ Abdel-Samiee ${ }^{3}$, Ashraf M Eljaky ${ }^{3}$, Osama Hammam ${ }^{1}$, Hassan Zaghla ${ }^{3}$, \\ Eman Abdelsameea ${ }^{3 *}$
}

\begin{abstract}
Several major risk factors for hepatocellular carcinoma (HCC) have been identified, including chronic infection of hepatitis B virus (HBV) and hepatitis $\mathrm{C}$ virus (HCV). Nevertheless, only a fraction of infected patients develops $\mathrm{HCC}$ during their lifetime suggesting that genetic factors might modulate HCC development. X-ray repair cross complementing group1 (XRCC1) participates in the repair pathways of DNA. Aim: to investigate the association between XRCC1 gene polymorphism and HCC in Egyptian chronic hepatitis C patients. Methods: This study was assessed on 40 patients with HCC secondary to chronic HCV infection who were compared to 20 cirrhotic HCV patients and 40- age and gender- matched healthy control group. After collection of relevant clinical data and basic laboratory tests, c. $1517 G>C S N P$ of $X R C C 1$ gene polymorphism was performed by (PCR-RFLP) technique. Results: A statistically higher frequency of $X R C C 1(\mathrm{CC}, \mathrm{GC})$ genotypes and increased $(\mathrm{C})$ allele frequency in patients with $\mathrm{HCC}$ was found in comparison to cirrhotic HCV patients as well as control group. In addition, patients with the XRCC1 (CC, GC) genotypes had significantly higher number and larger size of tumor foci and significantly higher Child Pugh grades. Multivariate analysis showed that the presence of $c .1517 G>C S N P$ of $X R C C 1$ gene is an independent risk for the development of HCC in chronic HCV patients with 3.7 fold increased risk of HCC development. In conclusion: XRCC1 gene polymorphism could be associated with increased risk of HCC development in chronic HCV Egyptian patients.
\end{abstract}

Keywords: XRCC1-SNP- Hepatocellular carcinoma- RFLP- DNA repair

Asian Pac J Cancer Prev, 21 (4), 1031-1037

\section{Introduction}

Hepatocellular carcinoma (HCC) is a worldwide health problem. In Egypt, it represents the second most common cancer in men and the sixth most common cancer in women (Omar et al., 2013). Hepatocellular carcinoma is the third cause of mortality due to cancer (El-Garawani et al., 2020). Several risk factors have been recognized, including chronic infection with hepatitis B virus (HBV) and hepatitis $\mathrm{C}$ virus (HCV) (Hasan et al., 2014). Chronic liver inflammation is associated with repair and tissue remodelling processes, which may lead to chromosomal damage and subsequent progression to cirrhosis and initiation of hepatocarcinogenesis (Gao et al., 2012).

DNA is under constant threat from endogenous and exogenous DNA damaging agents. Highly conserved DNA repair systems are settled to process DNA damage and maintain genomic integrity (Abbotts et al., 2014). Among these, the X-ray repair cross-complementing group 1 (XRCC1) which is responsible for repair of oxidative DNA damage and single-strand breaks (London, 2015).
$X R C C 1$ acts as a scaffolding protein that interacts with multiple repair enzymes allowing them to carry out their enzymatic steps in repairing DNA (Xu et al., 2015). $X R C C 1$ gene is located on chromosome 19q13.2-13.3. It spans a genetic distance of $33 \mathrm{~kb}$ comprising 17 exons. It encodes a 70-kDa protein which consists of 633 amino acids (Hanssen-Bauer et al., 2012).

Several studies indicated an association between $X R C C 1$ genetic polymorphisms and a variety of cancers such as gastric (Chen et al., 2016), lung (Cătană et al., 2015), thyroid (Wang et al., 2015) and breast cancer (Bu et al., 2014). This study aimed to investigate c.1517G $>C S N P$ of XRCC1 gene as HCC risk factor in Egyptian population.

\section{Materials and Methods}

\section{Subjects and Methods}

The present case control study was conducted in the National Liver Institute, Menoufia University in the period from June 2016 to June 2017. A total of 100 
subjects; 40 patients with HCC secondary to chronic HCV infection, 20 post hepatitis $\mathrm{C}$ cirrhotic patients - with no radiological evidence of HCC- and 40- age and gender- matched healthy control group were enrolled in the study.

The diagnosis of HCC was based on history taking, clinical examination, radiological examination including abdominal ultrasound and tri-phasic computed tomography (CT) of abdomen and laboratory investigations including hepatitis C and B markers and alpha-fetoprotein (AFP) level.

Patients with causes of liver cirrhosis and HCC other than chronic HCV infection were excluded like patients presented with chronic HBV infection, metabolic liver diseases, autoimmune liver diseases, fatty liver disease and alcoholic liver diseases.

The study protocol was approved by the local ethics committee of the Menoufia University. Informed consents were taken from both the patients and control group subjects before the beginning of the study.

\section{Routine laboratory investigations}

After collection of relevant clinical data, basic laboratory tests were performed including complete blood counts (Sysmex XT-1800i Automated Hematology Analyzer, Sysmex Corporation, Kobe 651-0073, Japan), liver function tests (cobas- 6000 auto analyser, Roche diagnostics- GmbH, D-68305 Mannheim, Germany), prothrombin concentration and international normalized ratio (INR) (BFT II Analyzer, Dade Behring Marburg GmbH, D-35041 Marburg, Germany), hepatitis serology (HBsAg and $\mathrm{HCV} \mathrm{Ab)} \mathrm{and} \mathrm{serum} \alpha$-fetoprotein level (cobas e411 immunoassay analyser, Roche diagnostics- GmbH, D-68305 Mannheim, Germany).

\section{DNA extraction and genotyping}

Venous blood sample was drawn from each subject and genomic DNA was extracted using Zymo Quick-gDNA ${ }^{\text {TM }}$ MiniPrep DNA Purification Kit (Zymo Research, CA, USA).

XRCC1 c. $1517 G>C$ polymorphism was detected using polymerase chain reaction-restriction fragment length polymorphism (PCR-RFLP) method as previously described (Bi et al., 2013). The 247 base pair (bp) fragment was amplified using the amplification mix in a total volume of $25 \mu \mathrm{l}$ which consisted of $1 \mu \mathrm{L}$ of each of primers; forward primer: 5'-CAAGTCCCAGCTGAGAACTGAG-3' and reverse primer: 5'- GCTGCTCTGCATGCTCACTC -3', $12.5 \mu \mathrm{l}$ of $\mathrm{MyTaq}^{\mathrm{TM}} \mathrm{Red}$ Mix master mix (2X) (Bioline, MA, USA), $5.5 \mu \mathrm{l}$ of nuclease-free water and $5 \mu \mathrm{l}$ of extracted genomic DNA.

The PCR amplification was performed on pre-programmed thermal cycler (Perkin Elmer Gene Amp PCR System 2400 Thermal Cycler version 2.11, USA) under the following conditions: an initial denaturation step at $94^{\circ} \mathrm{C}$ for $5 \mathrm{~min}$, followed by 35 cycles, $94^{\circ} \mathrm{C}$ for 35 seconds, annealing at $59^{\circ} \mathrm{C}$ for 35 seconds and $72^{\circ} \mathrm{C}$ for 35 seconds. Then final extension at $72^{\circ} \mathrm{C}$ for $5 \mathrm{~min}$ was carried out.

As a negative control, PCR mix without DNA sample was used to ensure contamination free PCR product.
Confirmation of successful PCR amplification was done using $2 \%$ agarose gel electrophoresis. Then $10 \mu \mathrm{l}$ of amplified DNA were digested at $37^{\circ} \mathrm{C}$ in a heat block for 5-15 min in a reaction mixture containing $1 \mu \mathrm{l} \mathrm{HaeIII}$ enzyme (New England Biolabs, MA, USA).

After digestion, fragments were separated on $2 \%$ agarose gel. HaeIII digests amplified DNA at the $\mathrm{C}$ allele, and yields two fragments; $168 \mathrm{bp}$ and $79 \mathrm{bp}$. Accordingly, samples yielding 168 and $79 \mathrm{bp}$ fragments were recorded as homozygous CC genotype, those yielding a single 247 bp fragment were recorded as homozygous GG genotype, while those yielding 247, 168 and 79 bp fragments were recorded as heterozygous GC genotype (Figure 1).

\section{Statistical analysis}

Results were collected, tabulated and statistically analysed by statistical package SPSS version 20 (Armonk, NK; IBM corporation). Data was expressed into two phases: Descriptive (number, percentage, mean and standard deviation) and analytical study (Chi-square test, Mann Whitney test, Kruskal-Wallis test, ANOVA test followed by Post Hoc Test (Dunn's multiple comparisons test), and Fisher's Exact test, Odds ratio (OR) and confidence interval $(\mathrm{CI})$ test) were used. $p$ value $>0.05$ was considered statistically non-significant and $p$ value $<0.05$ was considered statistically significant.

\section{Results}

Demographic and laboratory data of the studied groups

There was no significant difference among the three studied groups in terms of age and gender distribution (Table 1). However, as shown in Table 2, statistically significant difference between HCC group and control group was detected regarding platelet count, liver tests and AFP. On the other hand, comparing HCC group to cirrhotic group showed significantly higher aspartate aminotransferase (AST) and serum AFP levels and

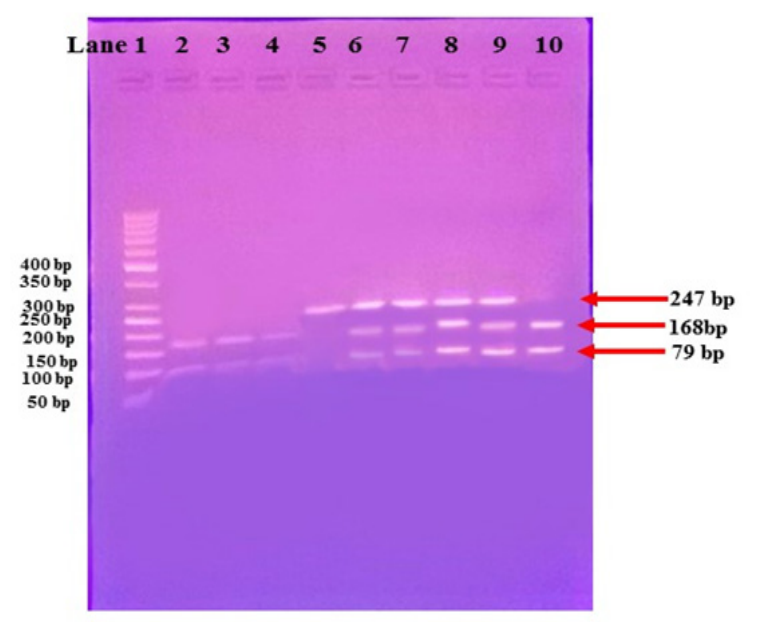

Figure 1. A Representative Agarose Gel Picture Showing PCR-RFLP Analysis of XRCC1 (c.1517G>C) Polymorphism of Studied Subjects after Digestion by HaeIII Restriction Enzyme. Lane 1 50-bp DNA ladder, lane $6,7,8$ and $9 \mathrm{G} / \mathrm{C}$ heterozygous $(247,168$ and $79 \mathrm{bp}$ bands), lane 2, 3, 4 and $10 \mathrm{C} / \mathrm{C}$ homozygous (168 and 79 bp bands) and lane $5 \mathrm{G} / \mathrm{G}$ homozygous (247 bp). 
Table 1. Demographic Characteristics of the Studied Groups

\begin{tabular}{|c|c|c|c|c|c|c|c|c|}
\hline & \multicolumn{2}{|c|}{ Group I (cirrhosis) $(\mathrm{n}=20)$} & \multicolumn{2}{|c|}{ Group II $(\mathrm{HCC})(\mathrm{n}=40)$} & \multicolumn{2}{|c|}{ Group III (Control) $(\mathrm{n}=40)$} & \multirow{2}{*}{$\begin{array}{c}\text { Test of } \\
\text { significance }\end{array}$} & \multirow[t]{2}{*}{$\mathrm{P}$} \\
\hline & No. & $\%$ & No. & $\%$ & No. & $\%$ & & \\
\hline \multicolumn{9}{|l|}{ Gender } \\
\hline Male & 16 & 80.0 & 36 & 90.0 & 28 & 70.0 & $\mathrm{c} 2=5.00$ & 0.082 \\
\hline Female & 4 & 20.0 & 4 & 10.0 & 12 & 30.0 & & \\
\hline \multicolumn{9}{|l|}{ Age (years) } \\
\hline Range & $41.0-62.0$ & & $42.0-63.0$ & & $41.0-59.0$ & & $\mathrm{~F}=2.58$ & 0.081 \\
\hline $\mathrm{SD} \pm$ Mean & $51.25 \pm 5.32$ & & $52.75 \pm 4.79$ & & $50.48 \pm 3.76$ & & & \\
\hline Median & 50.50 & & 52.50 & & 51.00 & & & \\
\hline
\end{tabular}

$\chi^{2} ; \mathrm{p}, \chi^{2}$ and $\mathrm{p}$ values for Chi square test for comparing between the three studied groups; F; $\mathrm{p}, \mathrm{F}$ and $\mathrm{p}$ values for ANOVA test

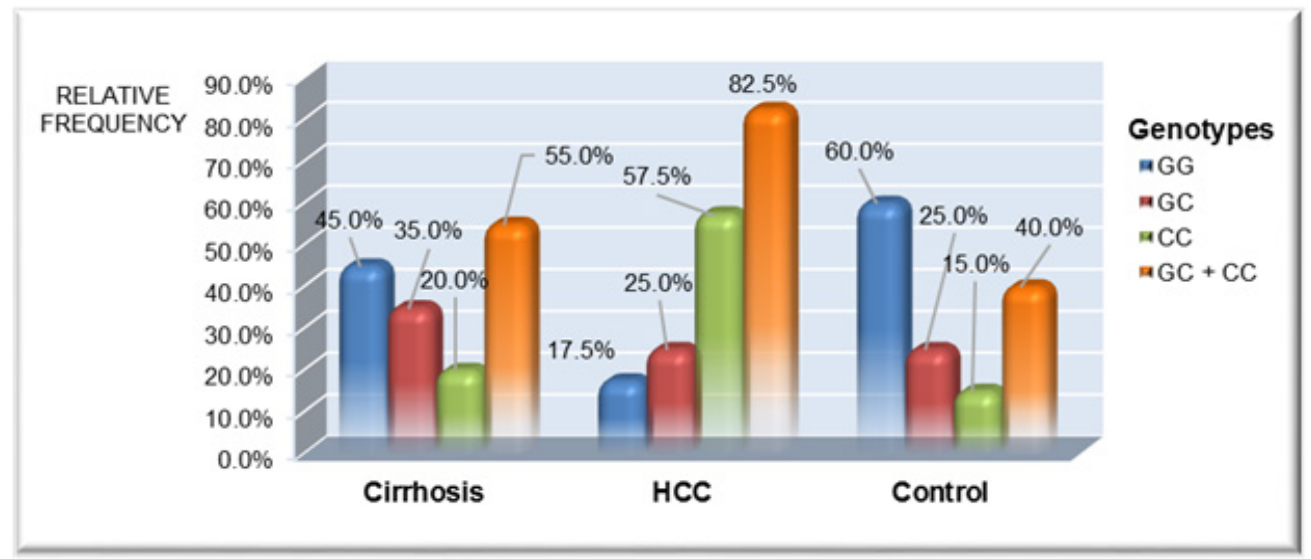

Figure 2. Comparison between the Different Studied Groups as Regard to XRCC1 (c.1517G>C) Genotype Distribution

significantly lower albumin levels with no statistical difference regarding platelet count, international normalized ratio (INR), alanine aminotransferase (ALT), total bilirubin, direct bilirubin and alkaline phosphatase.

XRCC1 genotype distribution and allele frequency among studied groups

Studying the frequency of different genotypes and alleles of XRCC1 (c.1517G>C) polymorphism among different studied groups are shown in Figures 2, 3 and Table 3. Control group showed significantly higher percentage of GG genotype versus
HCC group (60\% vs. $17.5 \%$, p value $<0.001)$ with significantly lower percent of C allele $(27.5 \%)$ versus HCC group $(70 \%, \mathrm{p}<0.001)$.

HCC patients had significantly higher incidence of CC and GC genotypes $(82.5 \%)$ when compared to healthy controls $(40 \%, \mathrm{p}<0.001)$ and cirrhotic patients $(55 \%, \mathrm{p}=0.023)$ with increased $\mathrm{C}$ allele frequency in patients with $\mathrm{HCC}$ in comparison to healthy controls as well as cirrhotic patients group ( $p<0.001$ and $\mathrm{p}=0.001$ respectively).

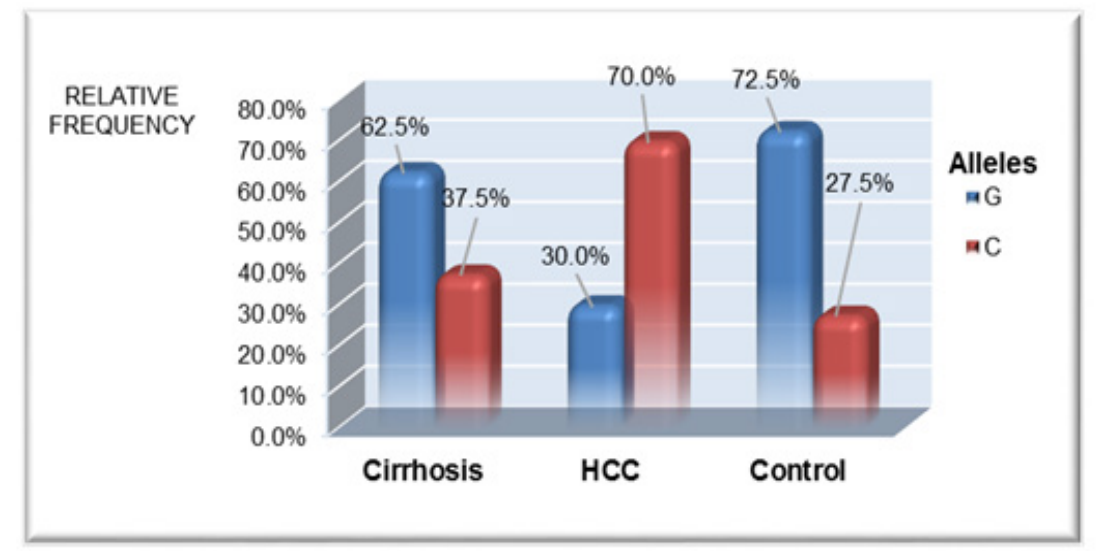

Figure 3. Comparison between the Different Studied Groups as Regard to Allele XRCC1 (c.1517G $>$ C) Frequency Distribution 
Table 2. Statistical Analysis of the Laboratory Results among the Studied Groups

\begin{tabular}{|c|c|c|c|c|c|c|}
\hline \multirow{3}{*}{ Laboratory parameters } & \multicolumn{3}{|c|}{ Studied groups } & \multirow{3}{*}{$\begin{array}{c}\text { Test of } \\
\text { significance }\end{array}$} & \multirow{3}{*}{$P$ value } & \multirow{3}{*}{ Significance } \\
\hline & & & & & & \\
\hline & $\begin{array}{l}\text { Group I (cirrhosis) } \\
\qquad(\mathrm{n}=20)\end{array}$ & $\begin{array}{l}\text { Group II (HCC) } \\
\qquad(\mathrm{n}=40)\end{array}$ & $\begin{array}{l}\text { Group III (Control) } \\
\qquad(\mathrm{n}=40)\end{array}$ & & & \\
\hline Platelets $\left(\times 10^{3} / \mu 1\right)$ & & & & & & $\mathrm{p}_{1}=0.517$ \\
\hline Range & $88.0-200.0$ & $31.0-231.0$ & $152.0-340.0$ & $\mathrm{H}=50.344^{*}$ & $<0.001 *$ & $\mathrm{p}_{2}<0.001 *$ \\
\hline Median & 126.5 & 107.5 & 210.5 & & & $\mathrm{p}_{3}<0.001 *$ \\
\hline INR & & & & & & $\mathrm{p}_{1}=0.889$ \\
\hline Range & $1.12-2.54$ & $1.07-4.50$ & $1.0-1.11$ & $\mathrm{H}=69.373^{*}$ & $<0.001 *$ & $\mathrm{p}_{2}<0.001^{*}$ \\
\hline Median & 1.55 & 1.58 & 1.01 & & & $\mathrm{p}_{3}<0.001^{*}$ \\
\hline AST (IU/L): & & & & & & $\mathrm{p}_{1}=0.004^{*}$ \\
\hline Range & $11.0-120.0$ & $35.0-2129.0$ & $10.0-25.0$ & $\mathrm{H}=70.068^{*}$ & $<0.001^{*}$ & $\mathrm{p}_{2}<0.001^{*}$ \\
\hline Median & 61.0 & 109.5 & 15.0 & & & $\mathrm{p}_{3}<0.001^{*}$ \\
\hline ALT (IU/L): & & & & & & $\mathrm{p}_{1}=0.930$ \\
\hline Range & $23.0-170.0$ & $11.0-748.0$ & $10.0-25.0$ & $\mathrm{H}=57.412 *$ & $<0.001 *$ & $\mathrm{p}_{2}<0.001 *$ \\
\hline Median & 45.50 & 54.50 & 16.0 & & & $\mathrm{p}_{3}<0.001^{*}$ \\
\hline $\operatorname{ALP}(\mathrm{IU} / \mathrm{L}):$ & & & & & & $\mathrm{p}_{1}=0.128$ \\
\hline Range & $45.0-364.0$ & $92.0-728.0$ & $46.0-89.0$ & $\mathrm{H}=62.466^{*}$ & $<0.001 *$ & $\mathrm{p}_{2}<0.001 *$ \\
\hline Median & 102.8 & 151.0 & 64.50 & & & $\mathrm{p}_{3}<0.001 *$ \\
\hline Albumin (g/dl): & & & & & & $\mathrm{p}_{1}=0.010^{*}$ \\
\hline Range & $2.10-3.60$ & $1.80-3.90$ & $3.70-5.0$ & $\mathrm{~F}=191.817$ & $<0.001 *$ & $\mathrm{p}_{2}<0.001^{*}$ \\
\hline Median & 2.60 & 2.20 & 4.35 & & & $\mathrm{p}_{3}<0.001 *$ \\
\hline Total bilirubin (mg/dl): & & & & & & $\mathrm{p}_{1}=0.409$ \\
\hline Range & $0.40-23.20$ & $0.75-15.70$ & $0.20-0.80$ & $\mathrm{H}=62.837^{*}$ & $<0.001 *$ & $\mathrm{p}_{2}<0.001 *$ \\
\hline Median & 3.83 & 3.44 & 0.53 & & & $\mathrm{p}_{3}<0.001^{*}$ \\
\hline Direct bilirubin $(\mathrm{mg} / \mathrm{dl})$ : & & & & & & $\mathrm{p}_{1}=0.614$ \\
\hline Range & $0.10-12.60$ & $0.22-12.07$ & $0.07-0.20$ & $\mathrm{H}=65.883$ & $<0.001^{*}$ & $\mathrm{p}_{2}<0.001 *$ \\
\hline Median & 1.40 & 2.08 & 0.11 & & & $\mathrm{p}_{3}<0.001 *$ \\
\hline $\operatorname{AFP}(n g / m L):$ & & & & $\mathrm{H}=63.660$ & $<0.001 *$ & $\mathrm{p}_{1}=0.002 * *$ \\
\hline Range & $1.63-4.0$ & $1.32-5882.0$ & $1.0-3.0$ & & & $\mathrm{p}_{2}=0.001^{*}$ \\
\hline Median & 2.85 & 52.0 & 1.60 & & & $\mathrm{p}_{3}<0.001 *$ \\
\hline
\end{tabular}

INR, International Normalized Ratio; AST, Aspartate aminotransferase; ALT, Alanine aminotransferase; ALP, Alkaline phosphatase; AFP, alfa fetoprotein; F,p, F and $p$ values for ANOVA test; Significance among groups was done using Post Hoc Test (LSD); H, p, H and p values for Kruskal Wallis test, Significance among groups was done using Post Hoc Test (Dunn's multiple comparisons test); *, Statistically significant at $\mathrm{p} \leq 0.05 ; \mathrm{p}_{1}$, $\mathrm{p}$ value for comparing between group I and group II; $\mathrm{p}_{2}, \mathrm{p}$ value for comparing between group I and group III; $\mathrm{p}_{3}, \mathrm{p}$ value for comparing between group II and group III

\section{XRCC1 gene polymorphism and the risk of hepatocellular carcinoma}

Univariate analysis revealed that the $\mathrm{CC}, \mathrm{GC}$ genotypes were associated with 3.857 increased risk of HCC compared to GG genotype. The multivariate analysis showed that the presence of $X R C C 1(\mathrm{c} .1517 \mathrm{G}>\mathrm{C})$ polymorphism is an independent risk for the development of HCC in chronic HCV patients with 3.742 fold increased risk of HCC development (Table 4).

In addition, patients with $\mathrm{CC}, \mathrm{GC}$ genotypes had significantly higher number of tumor foci $(p=0.006)$, and larger size of tumor foci $(\mathrm{p}=0.003)$ and advanced Child Pugh grade $(p=0.035)$ (Table 5).

In an attempt to study $\mathrm{CC}$ homozygous genotype as an independent factor affecting foci lesions in HCC group, we studied characteristics of focal lesions in relation to $c .1517 G>C C C$ homozygous genotype vs. GC and GG. However, there was no statistical significance between 2 groups regarding number of foci or focal size lesion ( $p=1.000,0.805$ respectively). In addition, there was no statistical difference regarding Child Pugh classification $(\mathrm{p}=0.497)$.

\section{Discussion}

As a complex and multi-factorial process, both genetic and environmental factors affect liver pathogenesis contributing to carcinogenesis (Parsa, 2012). Identifying those factors could guide understanding various pathways involved in hepatic carcinogenesis, this may improve screening policies for high risk patients.

DNA repair mechanisms interact to conserve genome integrity and avoid carcinogenesis. Base excision repair (BER) constitutes the primary defense against 
Table 3. Distribution of XRCC1 (c.1517G>C) Genotype and Allele Frequencies among the Studied Groups

\begin{tabular}{|c|c|c|c|c|c|c|c|c|c|}
\hline & \multicolumn{2}{|c|}{$\begin{array}{l}\text { Group I (cirrhosis) } \\
\qquad(\mathrm{n}=20)\end{array}$} & \multicolumn{2}{|c|}{$\begin{array}{l}\text { Group II (HCC) } \\
\qquad(\mathrm{n}=40)\end{array}$} & \multicolumn{2}{|c|}{$\begin{array}{l}\text { Group III (Control) } \\
\qquad(\mathrm{n}=40)\end{array}$} & \multirow[t]{2}{*}{$\chi^{2}$} & \multirow[t]{2}{*}{$\mathrm{p}$} & \multirow[t]{2}{*}{ Significance between groups } \\
\hline & No. & $\%$ & No. & $\%$ & No. & $\%$ & & & \\
\hline \multicolumn{10}{|l|}{ Genotypes } \\
\hline GG & 9 & 45.0 & 7 & 17.5 & 24 & 60.0 & \multirow[t]{3}{*}{$22.01 *$} & \multirow[t]{3}{*}{$<0.001^{*}$} & $\mathrm{P}_{1}=0.015^{*}$ \\
\hline GC & 7 & 35.0 & 10 & 25.0 & 10 & 25.0 & & & $\mathrm{P}_{2}=0.493 \mathrm{a}$ \\
\hline $\mathrm{CC}$ & 4 & 20.0 & 23 & 57.5 & 6 & 15.0 & & & $\mathrm{P}_{3}<0.001 *$ \\
\hline GG & 9 & 45.0 & 7 & 17.5 & 24 & 60.0 & \multirow{3}{*}{$15.31^{*}$} & \multirow[b]{2}{*}{$<0.001^{*}$} & $\mathrm{P}_{1}=0.023 *$ \\
\hline $\mathrm{GC}+\mathrm{CC}$ & 11 & 55.0 & 33 & 82.5 & 16 & 40.0 & & & $\begin{array}{c}\mathrm{P}_{2}=0.271 \\
\mathrm{P}_{3}<0.001^{*}\end{array}$ \\
\hline Alleles & & & & & & & & & $\mathrm{P}_{1}=0.001 *$ \\
\hline G & 25 & 62.5 & 24 & 30.0 & 58 & 72.5 & \multirow[b]{2}{*}{$30.67 *$} & \multirow[b]{2}{*}{$<0.001^{*}$} & $\mathrm{P}_{2}=0.263$ \\
\hline $\mathrm{C}$ & 15 & 37.5 & 56 & 70.0 & 22 & 27.5 & & & $\mathrm{P}_{3}<0.001 *$ \\
\hline
\end{tabular}

$\chi^{2}, p, \chi^{2}$ and $\mathrm{p}$ values for Chi square test for comparing between the three groups; Significance among groups was done using Fisher Exact test; $*$, Statistically significant at $\mathrm{p} \leq 0.05 ; \mathrm{p}_{1}, \mathrm{p}$ value for comparing between group I and group II; $\mathrm{p}_{2}, \mathrm{p}$ value for comparing between group I and group III; $\mathrm{p}_{3}, \mathrm{p}$ value for comparing between group II and group III

Table 4. Univariate and Multivariate Logistic Regression Analysis for HCC Cases

\begin{tabular}{|c|c|c|c|c|}
\hline & \multicolumn{4}{|c|}{ Univariate Analysis } \\
\hline & \multirow[t]{2}{*}{$P$ value } & \multirow[t]{2}{*}{ OR } & \multicolumn{2}{|c|}{$95 \% \mathrm{CI}$} \\
\hline & & & Lower & Upper \\
\hline Age (years) & 0.272 & 1.065 & 0.952 & 1.192 \\
\hline Gender (male) & 0.291 & 0.444 & 0.099 & 2.004 \\
\hline Viral load & 0.096 & 1.001 & 1.000 & 1.002 \\
\hline $\mathrm{XRCC} 1$ genotypes $(\mathrm{GC}+\mathrm{CC})$ & $0.028^{*}$ & 3.857 & 1.161 & 12.813 \\
\hline \multirow{4}{*}{$\begin{array}{l}\text { Child Pugh Classification } \\
(\mathrm{B}+\mathrm{C})\end{array}$} & 0.084 & 3.051 & 0.862 & 10.799 \\
\hline & \multicolumn{4}{|c|}{ Multivariate Analysis } \\
\hline & \multirow[t]{2}{*}{$\mathrm{P}$ value } & \multirow[t]{2}{*}{ Adjusted OR } & \multicolumn{2}{|c|}{$95 \% \mathrm{CI}$} \\
\hline & & & Lower & Upper \\
\hline Viral load & 0.127 & 1.001 & 1.000 & 1.002 \\
\hline XRCC1 Genotypes (GC+CC) & $0.042 *$ & 3.742 & 1.051 & 13.322 \\
\hline Child Pugh Classification & 0.198 & 2.438 & 0.627 & 9.475 \\
\hline
\end{tabular}

OR, Odds ratio; $\mathrm{CI}$, Confidence interval

Table 5. Comparison of XRCC1 Genotypes as Regard to HCC Characteristics

\begin{tabular}{|c|c|c|c|c|c|c|}
\hline & \multicolumn{4}{|c|}{ Results } & \multirow[t]{3}{*}{ Test of sig. } & \multirow[t]{3}{*}{$\mathrm{P}$} \\
\hline & \multicolumn{2}{|c|}{$\mathrm{GG}(\mathrm{n}=7)$} & \multicolumn{2}{|c|}{$\mathrm{GC}+\mathrm{CC}(\mathrm{n}=33)$} & & \\
\hline & No. & $\%$ & No. & $\%$ & & \\
\hline \multicolumn{7}{|l|}{ Number of foci } \\
\hline Single & 5 & 71.4 & 5 & 15.2 & \multirow[t]{2}{*}{$\chi^{2}=9.755^{*}$} & \multirow[t]{2}{*}{$\mathrm{FEp}=0.006^{*}$} \\
\hline Multiple & 2 & 28.6 & 28 & 84.8 & & \\
\hline \multicolumn{7}{|l|}{ Size $(\mathrm{cm})$} \\
\hline Max. - Min. & \multicolumn{2}{|c|}{$1.70-5.50$} & \multicolumn{2}{|c|}{$2.0-11.0$} & & \\
\hline $\mathrm{SD} \pm$ Mean & \multicolumn{2}{|c|}{$2.63 \pm 1.32$} & \multicolumn{2}{|c|}{$5.30 \pm 2.39$} & $\mathrm{U}=33.50^{*}$ & $0.003^{*}$ \\
\hline Median & \multicolumn{2}{|c|}{2.50} & \multicolumn{2}{|c|}{5.0} & & \\
\hline \multicolumn{7}{|c|}{ Child Pugh classification } \\
\hline A & 2 & 28.6 & 4 & 12.1 & \multirow{3}{*}{$\chi^{2}=6.08 *$} & \multirow{3}{*}{${ }^{\mathrm{FE}} \mathrm{p}=0.035^{*}, \mathrm{a}$} \\
\hline B & 3 & 42.9 & 4 & 12.1 & & \\
\hline $\mathrm{C}$ & 2 & 28.6 & 25 & 75.8 & & \\
\hline
\end{tabular}

$\chi^{2}, \mathrm{p}, \chi^{2}$ and $\mathrm{p}$ values for Chi square test; ${ }^{\mathrm{FE}} \mathrm{p}, \mathrm{p}$ value for Fisher Exact for Chi square test; U, $\mathrm{p}, \mathrm{U}$ and $\mathrm{p}$ values for Mann Whitney test; *, Statistically significant at $\mathrm{p} \leq 0.05$ 
lesions generated by ionizing radiation and strong alkylating agents, in addition to other DNA-damaging agents as viruses. $X R C C 1$ gene has been found to play a pivotal role in the base excision repair (BER) pathway. Mutations of XRCC1 may increase the risk of cancer through impairing its interaction with other enzymatic proteins with consequent impairment of DNA repair activity (Basso et al., 2007; Tudek, 2007).

Previous studies showed significant association between HCC and different SNPs in XRCC1 gene. Xia et al., (2014) noted that the genotypes and alleles distribution of $X R C C 1$ variants c. $910 \mathrm{~A}>\mathrm{G}$ and c. $1686 \mathrm{C}>\mathrm{G}$ were statistically associated with the risk of HCC. Liu et al., (2014) reported that c. $1804 \mathrm{C}>\mathrm{A}$ genetic polymorphism of XRCC1 may influence the risk of HCC (Liu et al., 2014). Kiran et al., (2009) found that Arg194Trp and Arg280His genotypes showed an increased risk of HCC which was further enhanced when Arg280His genotype was found in association with Arg194Trp and Arg399Gln. Also, Qi et al., in (2014) and Bazgir et al in (2018) noted that XRCC1 Arg399Gln polymorphism was associated with an increased risk of HCC. However, Liu et al., (2011) in their meta- analysis found no association between Arg399Gln polymorphism of $X R C C 1$ and the risk of HCC. Thus these results remain to be elucidated.

Previously c. $1517 \mathrm{G}>\mathrm{C}$ genetic variant of the $X R C C 1$ gene also was reported to be significantly associated with pancreatic cancer in a study conducted by Zhao et al., (2014) They noted that The CC genotype was significantly associated with an increased risk of pancreatic cancer. They reported that $\mathrm{C}$ allele may contribute to development of pancreatic cancer.

Our study aimed to investigate the association between $X R C C 1(c .1517 G>C)$ polymorphism and the risk of HCC in Egyptian patients who are chronically infected with $\mathrm{HCV}$. This genetic variant represents a non-synonymous $\mathrm{G}$ to $\mathrm{C}$ mutation in exon 14 of the $X R C C 1$ gene, resulting in glycine (Gly) to alanine (Ala) amino acid replace-ment (p.Gly506Ala) (Zhao et al., 2014).

We found statistically higher frequency of XRCC1 (CC, GC) genotypes in patients with HCC $(82.5 \%)$ in comparison to cirrhotic HCV patients $(55 \%)$ as well as control group (40\%) with higher percentage of $\mathrm{C}$ allele (70\%) in HCC group. The multivariate analysis revealed that the presence of $c .1517 G>C S N P$ of $X R C C 1$ gene was an independent risk factor for the development of HCC in chronic HCV patients with 3.7 fold increased risk of HCC development. Furthermore, patients with CC, GC genotypes had significantly higher number and larger size of tumour foci and advanced Child Pugh grades.

This was in agreement with Bi et al., (2013) who studied c. $1517 \mathrm{G}>\mathrm{C}$ and c. $1254 \mathrm{C}>\mathrm{T}$ polymorphisms in XRCC1 gene among HCC Chinese Han population. They found that there was statistically significant association between XRCC1 (CC, GC) genotypes and the risk of HCC. As in HCC group CC, GC and GG genotypes represented $15.21 \%, 47 \%$ and $37.79 \%$ respectively, with $\mathrm{CC} / \mathrm{GC}$ genotypes versus GG genotype OR 1.63 increased risk of HCC; $p<0.001$. They reported that the $\mathrm{C}$-allele of c. $1517 \mathrm{G}>\mathrm{C}$ genetic variants may influence the susceptibility to HCC ( $p<0.001)$. They also noted significant association between c. $1254 \mathrm{C}>\mathrm{T}$ polymorphism and HCC risk.

However, there was no statistical significance between c. $1517 \mathrm{G}>\mathrm{C} \mathrm{CC}$ homozygous genotype vs. GC and GG in $\mathrm{HCC}$ patients group regarding number of foci, focal size lesion or Child Pugh classification.

In conclusion, XRCC1 (c.1517G>C) polymorphism could be associated with increased risk of HCV-related HCC development in Egyptian population but the definite association between them needs to be validated in other large multicentre cohort studies.

\section{Compliance with Ethical Standards \\ Conflict of Interest}

Author Mary Naguib declares that she has no conflict of interest. Author Mohamed M Helwa declares that he has no conflict of interest. Author Mohammed M Soliman declares that he has no conflict of interest. Author Mohamed Abdel-Samiee declares that he has no conflict of interest. Ashraf M Eljaky declares that he has no conflict of interest. Author Osama Hammam declares that he has no conflict of interest. Author Hassan Zaghla declares that he has no conflict of interest and Author Eman Abdelsameea declares that she has no conflict of interest.

\section{Research involving human participants and/or animals Ethical approval}

All procedures performed in our study were in accordance with the ethical standards of the institutional and/or national research committee and with the 1964 Helsinki declaration and its later amendments or comparable ethical standards.

\section{Informed consent}

An informed consent was obtained from all individual participants included in the study.

\section{Ethical approval}

All procedures performed in our study were in accordance with the ethical standards of the institutional and/or national research committee and with the 1964 Helsinki declaration and its later amendments or comparable ethical standards.

\section{Informed consent}

An informed consent was obtained from all individual participants included in the study.

\section{References}

Abbotts R, Thompson N and Madhusudan S (2014). DNA repair in cancer: emerging targets for personalized therapy. Cancer Manag Res, 6, 77-92.

Basso D, Navaglia F, Fogar P, et al (2007). DNA repair pathways and mitochondrial DNA mutations in gastrointestinal carcinogenesis. Clin Chim Acta, 381, 50-5.

Bazgir A, Agha Gholizadeh M, Khosravi A,Mansour Samaei N (2017). The X-ray repair cross-complementing group 1 Arg399Gln genetic polymorphism and risk of hepatocellular carcinoma in an Iranian population, (2018). Middle East $J$ Dig Dis, 10, 40-4. 
Bi J, Zhong C, Li K, Chu H, Wang B (2013). Association study of single nucleotide polymorphisms in $X R C C l$ gene with risk of hepatocellular carcinoma in Chinese Han population. Biomed Res Int, 2 013, 138785.

Bu T, Liu L, Sun Y, et al (2014). XRCC1 Arg399G1n polymorphism confers risk of breast cancer in American Population: A meta-analysis of 10846 cases and 11723 controls. Miao X, ed. PLoS One, 9, e86086.

Cătană A, Pop M, Hincu BD, et al (2015). The XRCC1 Arg 194Trp polymorphism is significantly associated with lung adenocarcinoma: a case-control study in an Eastern European Caucasian group. Onco Targets Ther, 8, 3533-8.

Chen S, Zhu XC, Liu YL, Wang C, Zhang KG (2016). Investigating the association between XRCC1 gene polymorphisms and susceptibility to gastric cancer. Genet Mol Res, 15, doi: 10.4238/gmr.15038342.

El-Garawani I, Hassab El-Nabi S, Gadallah M, Abdelsameea E (2020). Association between IFN- $\lambda 3$ gene polymorphisms and outcome of treatment with direct acting antivirals in chronic HCV-infected Egyptian patients. Immunol Invest, 5, 1-11.

Gao J, Xie L, Yang W, et al (2012)., Risk factors of hepatocellular carcinoma-current status and perspectives. Asian Pac J Cancer Prev, 13, 743-52.

Hanssen-Bauer A, Solvang-Garten K, Akbari M, Otterlei M (2012). X-ray repair cross complementing protein 1 in base excision repair. Int J Mol Sci, 13, 17210-29.

Hasan A, Salah Y, Sayed M, et al (2014). Serum markers for the early detection of hepatocellular carcinoma in patients with chronic viral hepatitis C infection. Menoufia Med J, 27, 544-50.

Kiran M, Saxena R, Chawla YK, Kaur J (2009). Polymorphism of DNA repair gene XRCC1 and hepatitis-related hepatocellular carcinoma risk in Indian population. Mol Cell Biochem, 327, 7-13.

Liu F, Li B, Wei Y, et al (2011)., XRCC1 genetic polymorphism Arg399Gln and hepatocellular carcinoma risk: A metaanalysis. Liver Int, 1, 802-9.

Liu Y, Zhang A, Liu Y, Dong J (2014). Association analysis between the c. 1804C $>$ A genetic polymorphism of XRCC1 gene and risk of hepatocellular carcinoma in Chinese population. Med Oncol, 31, 854.

London RE (2015). The structural basis of XRCC1-mediated DNA repair. DNA Repair (Amst.), 30, 90-103

Omar A, Abou-Alfa G, Khairy A, Omar H (2013). Risk factors for developing hepatocellular carcinoma in Egypt. Chin Clin Oncol, 2, 43-51.

Parsa N (2012). Environmental factors inducing human cancers Iran J Public Health, 41, 1-9.

Qi Y, Cui L, Song Y, Li N(2014). XRCC1 Arg399Gln genetic polymorphism and the risk of hepatocellular carcinoma: a meta-analysis. Mol Biol Rep, 41, 879-87.

Tudek B (2007). Base excision repair modulation as a risk factor for human cancers. Mol Aspects Med, 28, 258-75.

Wang X, Zhang K, Liu X, et al (2015). Association between $\mathrm{XRCC} 1$ and $\mathrm{XRCC} 3$ gene polymorphisms and risk of thyroid cancer. Int J Clin Exp Pathol, 8, 3160-7.

Xia WF, Ma XP, Li XR, Dong H, Yi JL (2014). Association study of c. $910 \mathrm{~A}>\mathrm{G}$ and c. $1686 \mathrm{C}>\mathrm{G}$ polymorphisms in XRCC1 gene with risk of hepatocellular carcinoma in the Chinese population. Genet Mol Res, 13, 1314-22.

Xu W, Liu SA, Li L, Shen ZY, Wu YL (2015). Association between XRCC1 Arg280His polymorphism and risk of hepatocellular carcinoma: a systematic review and metaanalysis. Genet Mol Res, 14, 7122-9.

Zhao ZM, Li CG, Hu MG, Gao YX, Liu R (2014). Influence of the c. $1517 \mathrm{G}>\mathrm{C}$ genetic variant in the XRCC1 gene on
XRCC1 Gene Polymorphism in Hepatocellular Carcinoma

pancreatic cancer susceptibility in a Chinese population. Genet Mol Res, 13, 4466-72.

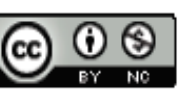

This work is licensed under a Creative Commons AttributionNon Commercial 4.0 International License. 